\title{
Seroprevalence and Trends of Enterally Transmitted Hepatitis Viruses in a Tertiary Care Hospital: A 3-year Study
}

\author{
Veenu Gupta ${ }^{1}$, Deepinder Chhina ${ }^{2}$, Neha Mittal ${ }^{3}$
}

\begin{abstract}
Background and objectives: Despite the significant achievements in recent decades to control viral hepatitis worldwide, hepatitis A virus (HAV) and hepatitis E virus (HEV) infections remain a matter of significant public health concern. Both viruses are transmitted primarily by orofecal route and are present higher in communities with poor sanitation. They cause a disease that is indistinguishable without serologic testing. Prevalence of HEV is less frequent even in endemic areas (7.8-45\%), compared to HAV infection (up to 100\% in low-income countries). The present study was undertaken to investigate the prevalence of HAV and HEV and to study their seasonal variations.

Materials and methods: This was a retrospective study over a period of 3 years. Serum samples from patients suspected of viral hepatitis were tested for anti-HAV and anti-HEV immunoglobulin (Ig) M antibodies by enzyme-linked immunosorbent assay (ELISA). Seasonal trends of HAV and HEV were also studied.

Results: The overall percentage positivity for $\mathrm{HAV}$ and $\mathrm{HEV}$ was $15.4 \%$ and $13.9 \%$ and the prevalence was more in the males. Majority of cases of HAV infection were in the age-group of 11-20 years, whereas HEV infection was predominant in the age-group of 21-30 years. There was a year-wise increasing trend of HAV and HEV seroprevalence. On comparing the seasonal trends, hepatitis A was more during the monsoon (17.6\%) and hepatitis $E$ was more during the summer season (15.1\%).
\end{abstract}

Conclusion: The prevalence of hepatitis $A$ was more when compared to hepatitis $E$, and majority of the patients were males.

Keywords: Hepatitis A virus, Hepatitis E virus, Prevalence, Viral hepatitis.

Journal of Gastrointestinal Infections (2019): 10.5005/jp-journals-10068-3032

\section{INTRODUCTION}

Communicable diseases are still the major health problem in our country, and the hepatitis viruses residing in India are usually the endemic forms. Viral hepatitis can be defined as inflammation of liver due to infection of any of the hepatotropic viruses. ${ }^{1}$ These hepatotropic viruses are divided into enteral and parenteral groups on the basis of their mode of transmission. Both hepatitis A virus (HAV) and hepatitis E virus (HEV) are enterally transmitted by the orofecal route and do not exist in a chronic carrier state. Hepatitis $B$ virus (HBV), hepatitis $C$ virus (HCV), and hepatitis D virus are parenterally transmitted, occur in both acute and chronic forms, and serve as a reservoir for infection when they persist in a chronic carrier state. They have the potential to cause chronic hepatitis, cirrhosis, and hepatocellular carcinoma. ${ }^{2}$

Viral hepatitis is reporting from almost all countries in the world, and it is considered as a global public health problem associated with substantial morbidity and mortality. ${ }^{3}$ This is also a serious problem in India and has been reported from all parts of this country. ${ }^{4}$ The World Health Organization (WHO) executive board ${ }^{1}$ certifies that 10 lakh people die each year due to the causes related to viral hepatitis, which is $2.7 \%$ of the total deaths that occur in the world. Some groups are at high risk of contracting this disease compared with others. Both HAV and HEV are found higher in communities where food and sanitation are poor, and HBV and $\mathrm{HCV}$ infections are seen more common among the recipients of organs, blood, and tissues and also among the healthcare providers who sustain accidental needle stick injuries. ${ }^{5}$ The symptoms of acute infections are jaundice, dark urine, extreme fatigue, nausea, vomiting, and abdominal pain. ${ }^{6}$

Known for its global distribution, ${ }^{7}$ HAV is a nonenveloped 27-nm, ribonucleic acid (RNA) virus of the genus Hepatovirus of the

\begin{abstract}
${ }^{1-3}$ Department of Microbiology, Dayanand Medical College and Hospital, Ludhiana, Punjab, India

Corresponding Author: Veenu Gupta, Department of Microbiology, Dayanand Medical College and Hospital, Ludhiana, Punjab, India, Phone: +91 9814736051, e-mail: vsunilgupta@rediffmail.com

How to cite this article: Gupta V, Chhina D, Mittal N. Seroprevalence and Trends of Enterally Transmitted Hepatitis Viruses in a Tertiary Care Hospital: A 3-year Study. J Gastrointest Infect 2019;9(1):23-27.

Source of support: Nil

Conflict of interest: None
\end{abstract}

family Picornaviridae. Antibodies to HAV (anti-HAV) can be detected during acute illness when the serum aminotransferase activity is elevated and fecal HAV shedding is still occurring. Hepatitis $E$ virus (HEV) occurs primarily in Asia, Africa, and Central America. It is a nonenveloped virus with a single-stranded positive-sense RNA of the genus Hepevirus of the family Hepeviridae. ${ }^{8}$ Both HAV and HEV display considerable differences regarding their nature and epidemiology. Immunity to HAV is lifelong, and infection is often acquired early in life, while most of the HEV infections occur in late childhood or young adulthood.

Hepatitis A virus (HAV) infection is a common infection responsible for about 1.4 million new infections worldwide each year. ${ }^{9}$ Studies conducted in India by Acharya et al. ${ }^{10}$ and Nanda et al. ${ }^{11}$ also observed that enteric hepatitis is highly endemic in India. Studies reveal that HAV is a predominant cause of viral hepatitis, ${ }^{12}$ and it constitutes around $32.1 \%$ of the total viral hepatitis reported all over the world. ${ }^{13}$ Kunasol et al. ${ }^{14}$ reported that India was highly endemic for HAV. In India, HEV causes acute sporadic hepatitis in $30-70 \%$ cases and is the major cause of liver failure. ${ }^{11}$ India is

(c) The Author(s). 2019 Open Access This article is distributed under the terms of the Creative Commons Attribution 4.0 International License (https://creativecommons. org/licenses/by-nc/4.0/), which permits unrestricted use, distribution, and non-commercial reproduction in any medium, provided you give appropriate credit to the original author(s) and the source, provide a link to the Creative Commons license, and indicate if changes were made. The Creative Commons Public Domain Dedication waiver (http://creativecommons.org/publicdomain/zero/1.0/) applies to the data made available in this article, unless otherwise stated. 
hyperendemic for HAV and HEV. ${ }^{10}$ Thus, the present study was undertaken to find the prevalence of HAV and HEV and to study seasonal variations for 3 years.

\section{Materials and Methods}

This was a 3-year retrospective study (July 2016 to June 2019). The study population included individuals from all age-groups who were suspected of acute viral hepatitis. This study was approved by the Institutional Ethics Committee. From each patient, about 5-10 $\mathrm{mL}$ of venous blood was collected in a vacutainer without anticoagulant. Serum was separated after centrifugation and then stored at $4^{\circ} \mathrm{C}$ until further processing. These sera were tested for anti-HAV IgM (Roche Diagnostics India Pvt. Ltd.), and anti-HEV IgM (Beijing WANTAI Biological Pharmacy Enterprise Co. Ltd., Beijing), by ELISA. Tests were carried out per the manufacturer's guidelines and interpreted as reactive or nonreactive. Seasonal trends of HAV and HEV for winter (November to February), summer (March to June), and monsoon (July to October) were also studied.

\section{Results}

A total of 4,878 samples were received for HAV and 4,858 samples for HEV, of which 755 were positive for HAV and 680 were positive for HEV. The overall percentage positivity for HAV and HEV was $15.4 \%$ and $13.9 \%$. There was year-wise increasing trend of HAV seroprevalence $(10.4 \%, 14.4 \%$, and $20.5 \%)$ and HEV seroprevalence (13.3\%, 13.8\%, and 14.6\%) in 2016-2017, 2017-2018, and 2018-2019, respectively (Fig. 1) The prevalence of both viral HAV and HEV was more in males (73.2\% and $72.1 \%$ ) compared to females (Table 1$)$. The majority of cases of HAV infection (42.2\%) were in the age-group of 11 to 20 years, whereas HEV infection was predominant (30.4\%) in the age-group of 21 to 30 years (Table 2). On comparing the seasonal trends, the overall seroprevalence of HAV observed was $17.6 \%$,

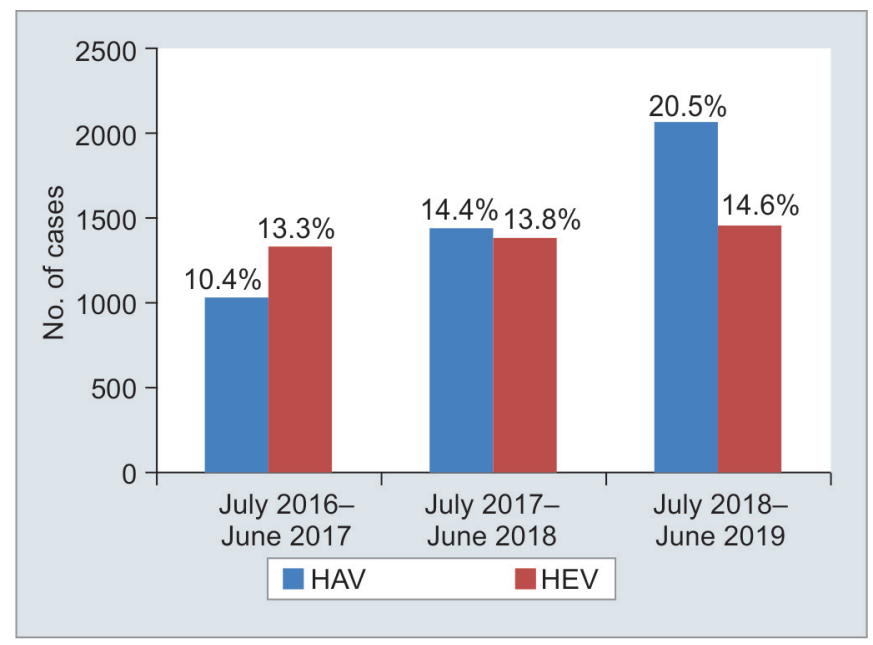

Fig. 1: Year-wise seroprevalence of hepatitis $A$ and $E$
$11.2 \%$, and $16.5 \%$ and HEV $12.6 \%, 14.5 \%$, and $15.1 \%$ in monsoon, winter, and summer seasons, respectively (Table 3, Figs 2 and 3).

\section{Discussion}

Viral hepatitis is a major public health problem throughout the world. Moreover, all types of viruses, already characterized and identified as the causative agent of viral hepatitis infect Indian population. ${ }^{14}$ In our study, among the two enterally transmitted viruses, the overall prevalence of HAV (15.4\%) was more than HEV (13.9\%). Singh et al. ${ }^{13}$ and Joon et al. ${ }^{15}$ reported the HAV seropositivity was more (32.1\% and $19.31 \%)$ than that of HEV $(7.19 \%$ and 10.54\%). In contrast to our study, Kumar et al., ${ }^{16}$ Nandi et al., ${ }^{17}$ Antony and Celine ${ }^{18}$ Manmohan et al., ${ }^{19}$ and Mittal et al. ${ }^{20}$ reported higher prevalence of HEV $(37.4 \%, 45.4 \%, 61.24 \%, 37.49 \%$, and $14.9 \%$ respectively) as compared to HAV (14.6\%, 33\%, 31.54\%, 32\%, and $7.67 \%$, respectively). It is supported by other studies conducted by various authors. ${ }^{21-24}$

The overall incidence of both HAV and HEV was more in males (73.1\% and $72.1 \%$ ), and this finding is similar to that reported by Mittal et al. $(63.7 \% \text { and } 69.7 \%)^{20}$ and Joon et al. $(68 \%$ and $79 \%)^{15}$ In literature, similar results were observed in other studies also. $^{13,18,24-27}$ It is because of greater exposure of males in their professional and social activities. In a study by Antony, Celine ${ }^{18}$ and Barrientos Gutierrez et al., ${ }^{28}$ higher HAV infection was seen in males (80.62\% and $77.2 \%$ ) than females. But Faleh et al. ${ }^{29}$ in their study on the changing patterns of HAV prevalence observed no difference among males and females. Various studies in literature also reported higher prevalence of HEV infection in males compared to that in females. ${ }^{19,30,31}$

In our study, among the enterally transmitted viruses, most of the patients infected with hepatitis A were in the age-group of 11-20 years, which is similar to the findings of many studies. ${ }^{17,24,31}$ In contrast, higher HAV infection in adults $(60.85 \%$ in $20-39$ years $)_{,}^{18}(65 \% \text { in } 15-33 \text { years })^{32}$ was reported in literature. In the present study, the highest proportion of cases of HEV infection was in 21-30 years, which is similar to that reported by Antony and Celine $^{18}\left(52.29 \%\right.$ in $20-39$ years) and Begum et al. ${ }^{33}$ (71.9\% in 20-24 years). In present study, majority of hepatitis $A$ cases were in the age-group 11-20 (42.2\%) and hepatitis $E$ in the age-group 21-30 years (30.4\%) similar to that reported by Mittal et al. ${ }^{20}$ (45.6\% and $37.6 \%)$, respectively. The present study has shown that HEV infection occur more often in older children and adults (21-30 years), whereas HAV occurs mostly in young children (11-20 years). This finding is consistent with other studies conducted in India and shows that exposure to HAV occurs early in life. Hepatitis E virus infection is less common in young children as anicteric hepatitis or subclinical infections are common in children. ${ }^{34}$

In our study, the overall incidence of HAV infection was more during the monsoon season (17.6\%), which are similar to the findings in literature. ${ }^{13,24}$ In contrast to the present study, Al-Naaimi et al. ${ }^{26}$ reported hepatitis $\mathrm{A}$ infection more in winter.

Table 1: Sex-wise distribution of hepatitis A virus (HAV) and hepatitis E virus (HEV) positive cases

\begin{tabular}{|c|c|c|c|c|c|c|}
\hline & \multicolumn{2}{|c|}{ HAV } & \multirow[t]{2}{*}{ Total } & \multicolumn{2}{|c|}{ HEV } & \multirow[t]{2}{*}{ Tota } \\
\hline & Male & Female & & Male & Female & \\
\hline $2016-17$ & $110(71.9)$ & $43(28.1)$ & 153 & 135 (69.9) & $58(30.1)$ & 193 \\
\hline 2017-18 & $177(75)$ & $59(25)$ & 236 & $169(73.8)$ & $60(26.2)$ & 229 \\
\hline 2018-19 & $265(72.4)$ & $101(27.6)$ & 366 & $186(72.1)$ & 72 (21.9) & 258 \\
\hline Total & 552 (73.1) & 203 (26.9) & 755 & $490(72.1)$ & 190 (27.9) & 680 \\
\hline
\end{tabular}


Enterally Transmitted Hepatitis Viruses

Table 2: Age-wise distribution of hepatitis A virus (HAV)- and hepatitis E virus (HEV)-positive cases

\begin{tabular}{|c|c|c|c|c|c|c|c|c|}
\hline \multirow[b]{2}{*}{ Age (years) } & \multirow[b]{2}{*}{$2016-17$} & \multicolumn{2}{|c|}{ HAV } & \multirow[b]{2}{*}{ Total } & \multirow[b]{2}{*}{$2016-17$} & \multicolumn{2}{|c|}{ HEV } & \multirow[b]{2}{*}{ Total } \\
\hline & & 2017-18 & 2018-19 & & & 2017-18 & 2018-19 & \\
\hline $0-10$ & 19 (12.4) & $26(0.1)$ & $70(19.1)$ & $115(15.2)$ & $4(2)$ & $3(1.3)$ & $6(2.3)$ & $13(1.9)$ \\
\hline $11-20$ & 61 (39.9) & $107(45.3)$ & $151(41.2)$ & $319(42.2)$ & $6(3.1)$ & 25 (10.9) & $31(12)$ & $62(9.1)$ \\
\hline $21-30$ & 60 (39.2) & 87 (36.9) & $126(34.4)$ & $273(36.1)$ & 65 (33.7) & $55(24)$ & $87(33.7)$ & $207(30.4)$ \\
\hline $31-40$ & $10(6.53)$ & $10(4.2)$ & $16(4.4)$ & $36(4.7)$ & $41(21.2)$ & 41 (17.9) & $62(22)$ & $124(18.2)$ \\
\hline $41-50$ & $2(1.3)$ & $5(2.1)$ & $2(0.5)$ & $9(1.2)$ & 26 (13.5) & 38 (16.6) & $42(16.3)$ & $106(15.5)$ \\
\hline $51-60$ & $1(0.6)$ & $1(0.4)$ & $1(0.3)$ & $3(0.4)$ & $26(13.5)$ & 38 (16.6) & $8(3.1)$ & $72(10.5)$ \\
\hline $61-70$ & - & - & - & - & $14(7.2)$ & $24(10.5)$ & 17 (6.6) & $55(8)$ \\
\hline $71-80$ & - & - & - & - & - & $5(2.2)$ & $4(1.5)$ & $9(1.3)$ \\
\hline $81-90$ & - & - & - & - & $1(0.5)$ & - & $1(0.3)$ & $2(0.3)$ \\
\hline Total & 153 & 236 & 366 & 755 & 183 & 229 & 258 & 680 \\
\hline
\end{tabular}

Table 3: Seasonal trends of hepatitis A virus and hepatitis E virus

\begin{tabular}{|c|c|c|c|c|c|c|c|c|}
\hline & \multicolumn{3}{|c|}{ HAV } & \multirow[b]{2}{*}{ Total } & \multicolumn{3}{|c|}{ HEV } & \multirow[b]{2}{*}{ Total } \\
\hline & $\begin{array}{l}\text { Jul-Oct } \\
\text { (Monsoon) }\end{array}$ & $\begin{array}{r}\text { Nov-Feb } \\
\text { (Winter) }\end{array}$ & $\begin{array}{l}\text { Mar-Jun } \\
\text { (Summer) }\end{array}$ & & $\begin{array}{l}\text { Jul-Oct } \\
\text { (Monsoon) }\end{array}$ & $\begin{array}{l}\text { Nov-Feb } \\
\text { (Winter) }\end{array}$ & $\begin{array}{l}\text { Mar-Jun } \\
\text { (Summer) }\end{array}$ & \\
\hline July 16-June 17 & $\begin{array}{l}75 / 580 \\
(12.9 \%)\end{array}$ & $\begin{array}{l}29 / 422 \\
(6.8 \%)\end{array}$ & $\begin{array}{l}49 / 458 \\
(10.6 \%)\end{array}$ & $\begin{array}{l}153 / 1460 \\
(10.4 \%)\end{array}$ & $\begin{array}{l}60 / 569 \\
(10.6 \%)\end{array}$ & $\begin{array}{l}54 / 423 \\
(12.7 \%)\end{array}$ & $\begin{array}{l}79 / 445 \\
(17.7 \%)\end{array}$ & $\begin{array}{l}193 / 1444 \\
(13.3 \%)\end{array}$ \\
\hline July 17-June 18 & $\begin{array}{l}144 / 644 \\
(22.3 \%)\end{array}$ & $\begin{array}{l}44 / 473 \\
(9.3 \%)\end{array}$ & $\begin{array}{l}48 / 518 \\
(9.2 \%)\end{array}$ & $\begin{array}{l}236 / 1635 \\
(14.4 \%)\end{array}$ & $\begin{array}{l}102 / 695 \\
(14.6 \%)\end{array}$ & $\begin{array}{l}69 / 459 \\
(15 \%)\end{array}$ & $\begin{array}{l}58 / 498 \\
(11.6 \%)\end{array}$ & $\begin{array}{l}229 / 1652 \\
(13.8 \%)\end{array}$ \\
\hline July 18- June 19 & $\begin{array}{l}114 / 659 \\
(17.29 \%)\end{array}$ & $\begin{array}{l}85 / 507 \\
(16.7 \%)\end{array}$ & $\begin{array}{l}167 / 617 \\
(27.1 \%)\end{array}$ & $\begin{array}{l}366 / 1783 \\
(20.5 \%)\end{array}$ & $\begin{array}{l}80 / 648 \\
(12.3 \%)\end{array}$ & $\begin{array}{l}80 / 510 \\
(15.6 \%)\end{array}$ & $\begin{array}{l}98 / 604 \\
(16.2 \%)\end{array}$ & $\begin{array}{l}258 / 1762 \\
(14.6 \%)\end{array}$ \\
\hline Total & $\begin{array}{l}333 / 1883 \\
(17.6 \%)\end{array}$ & $\begin{array}{l}158 / 1402 \\
(11.2 \%)\end{array}$ & $\begin{array}{l}264 / 1593 \\
(16.5 \%)\end{array}$ & $\begin{array}{l}755 / 4878 \\
(15.4 \%)\end{array}$ & $\begin{array}{l}242 / 1912 \\
(12.6 \%)\end{array}$ & $\begin{array}{l}203 / 1392 \\
(14.5 \%)\end{array}$ & $\begin{array}{l}235 / 1547 \\
(15.1 \%)\end{array}$ & $\begin{array}{l}680 / 4858 \\
(13.9 \%)\end{array}$ \\
\hline
\end{tabular}

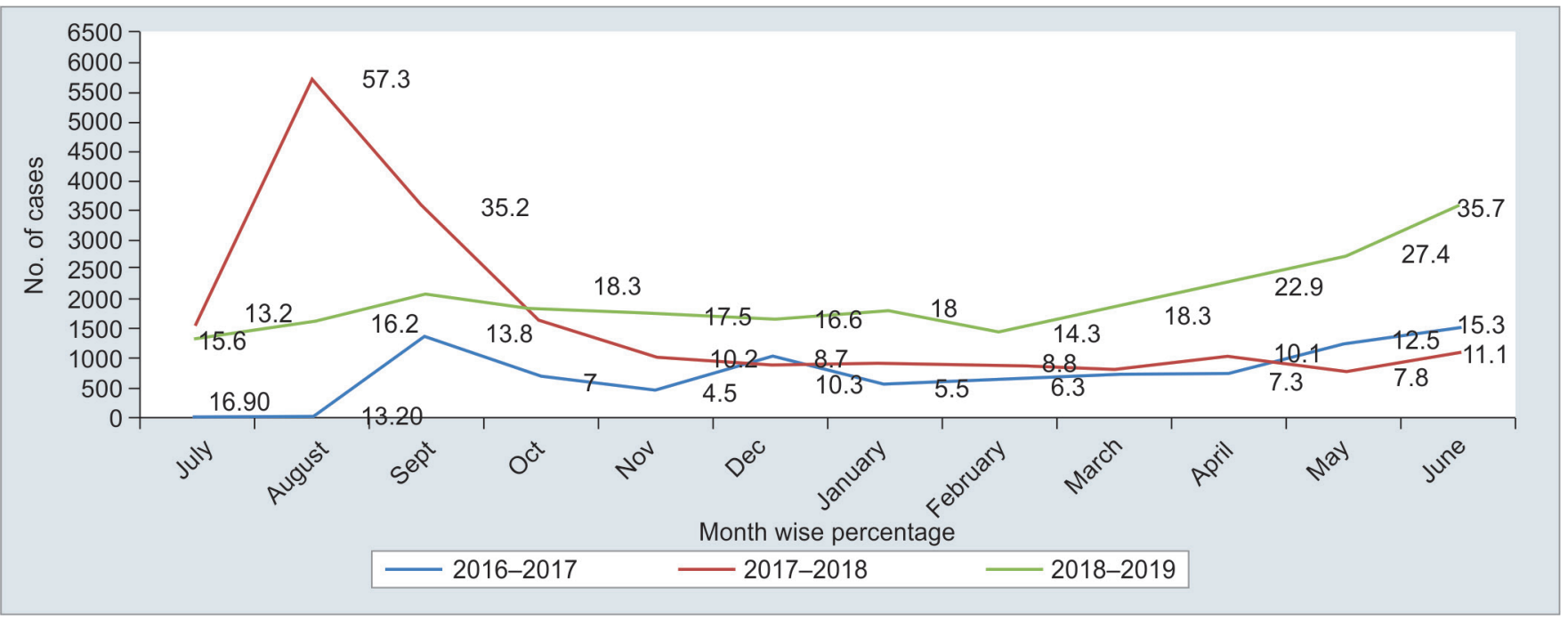

Fig. 2: Trends of hepatitis A in 3 years

Hepatitis E virus infection was more in summer (15.19\%) similar to that reported by various authors. ${ }^{26,35}$ However, Suri et al. ${ }^{24}$ reported maximum positivity of HEV infection in winter. Mittal et al. ${ }^{20}$ observed that HAV and HEV infection occurred throughout the year, with maximum number of patients in summer and in the beginning of rainy season. Joon et al. ${ }^{15}$ reported predominance of HAV and HEV infection toward the end of monsoon and beginning of winter and a peak rise in HEV during the beginning of rainy season.

\section{Conclusion}

In our study, the prevalence of hepatitis A was more than hepatitis $E$ in enterally transmitted viruses, making them a major public health problem in our area. The disease can lead to significant economic and social consequences in communities. As contaminated food and water is the main mode of transmission, much emphasis should be given for the environmental and personal hygiene practices to prevent the orofecal transmission of these pathogens. This study highlights the need for early screening of clinically diagnosed 


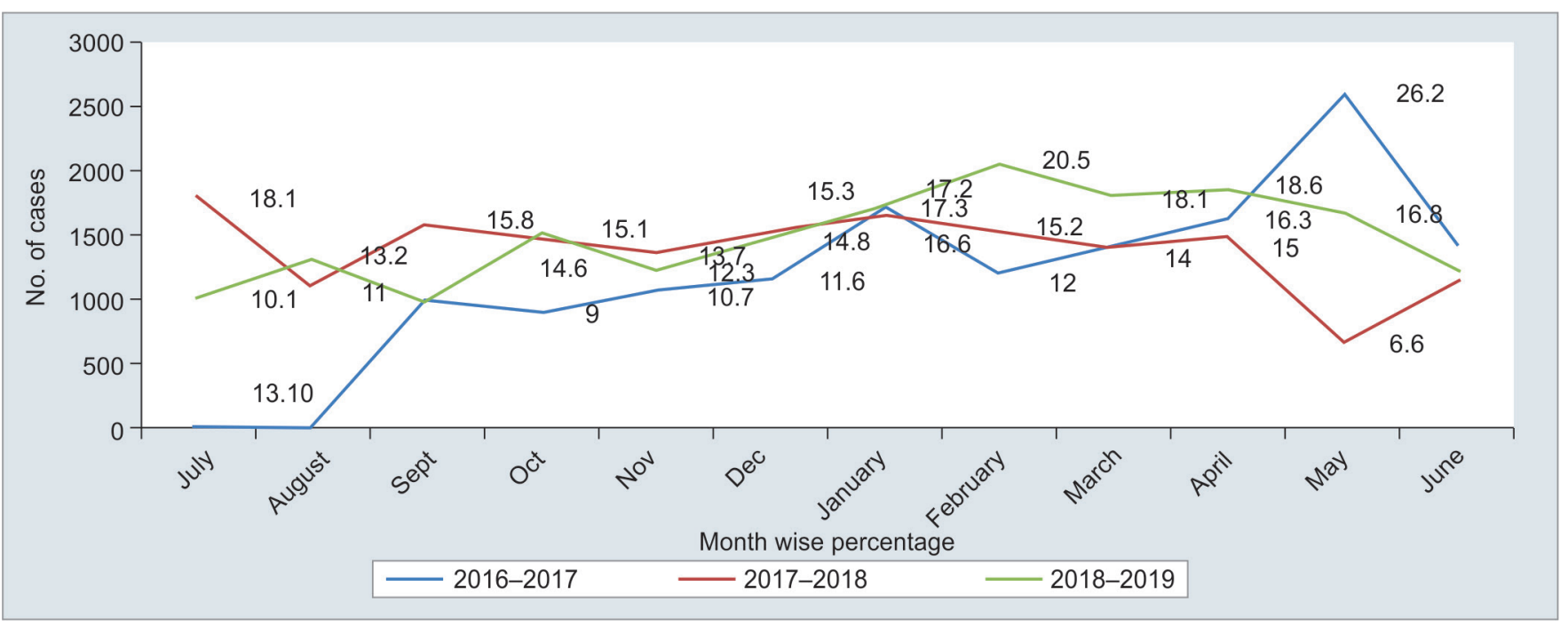

Fig. 3: Trends of hepatitis $E$ in 3 years

cases of viral hepatitis, so that appropriate precautions can be implemented to decrease the prevalence of these emerging infections.

\section{ACKnOWLedgment}

The authors would like to acknowledge the technical assistance provided by Mr Sukhvinder Singh.

\section{References}

1. WHO Executive Board. Viral hepatitis. Report by the secretariat, 2009. EB126/15.12 November 2009.

2. Sulkowski MS, Chaisson RE. Gastrointestinal and Hepatobiliary manifestations of human immunodeficiency virus infection. In: Mandell GL, Bennett JE, Dolin R. Principles and Practice of Infectious Diseases, 6th ed., Philadelphia PA: Elsevier; 2005. p. 1426.

3. World Health Organization. Sixty-third World Health Assembly. Viral Hepatitis WHA 63.18. Geneva, Switzerland 2010.

4. Irshad $M$, Singh $S$, Ansari $M A$, et al. Viral hepatitis in India: a report from Delhi. Glob J Health Sci 2010;2(2):96-103.

5. Abou MA, Eltahir YM. Seropositivity of hepatitis B virus and hepatitis $C$ virus dual infection among blood donors in Nyala teaching hospital. Virol J 2009;6:227. DOI: 10.1186/1743-422X-6-227.

6. Ryder SD, Beckingham IJ. ABC of diseases of liver, pancreas, and biliary system: acute hepatitis. BMJ 2001;322(7279):151-153. DOI: 10.1136/ bmj.322.7279.151.

7. Jacobsen KH, Koopman JS. Declining hepatitis a seroprevalence: a global review and analysis. Epidemiol Infect 2004;132(6):1005-1022. DOI: 10.1017/S0950268804002857.

8. Braunwald E, Fauci AS, Kasper DL, et al. Harrison's Principles of Internal Medicine, 5th ed., 2001. pp. 1694-1710.

9. World Health Organization. Hepatitis a vaccines: WHO position paper. Wkly Epidemiol Rec 2000;75:38-44.

10. Acharya SK, Batra Y, Bhatkal B, et al. Seroepidemiology of hepatitis a virus infection among school children in Delhi and north Indian patients with chronic liver disease: implications for HAV vaccination. J Gastroenterol Hepatol 2003;18:822-827. DOI: 10.1046/j.14401746.2003.03051.x.

11. Nanda SK, Yalcinkaya K, Panigrahi AK, et al. Etiological role of hepatitis Evirus in sporadic fulminant hepatitis. J Med Virol 1994;42(2):133-137. DOI: $10.1002 / j m v .1890420207$.

12. Karagöz G, Ak O, Ozer $\mathrm{S}$. The coexistence of hepatitis $A$ and infectious mononucleosis. Turk J Gastroenterol 2005;16:102-104.
13. Singh J, Prakash C, Gupta RS, et al. Epidemiology of endemic viral hepatitis in an urban area of India: a retrospective community study in Alwar. Bull World Health Organ 1997;75(5):463-468.

14. Kunasol P, Cooksley G, Chan VF, et al. Hepatitis A virus: declining seroprevalence in children and adolescents in Southeast Asia. Southeast Asian J Trop Med Public Health 1998;29(2):255-262.

15. Joon A, Rao P, Shenoy SM, et al. Prevalence of hepatitis A virus (HAV) and hepatitis $E$ virus (HEV) in the patients presenting with acute viral hepatitis. Indian J Med Microbiol 2015;33(Supplement 1):S102-S105. DOI: 10.4103/0255-0857.150908.

16. Kumar S, Ratho RK, Chawla YK, et al. The incidence of sporadic viral hepatitis in North India: a preliminary study. Hepatobiliary Pancreat Dis Int 2007;6(6):596-599.

17. Nandi B, Hadimani $P$, Arunachalam $R$, et al. Spectrum of acute viral hepatitis in Southern India. MJAFI 2009;65(1):7-9.

18. Antony J, Celine TM. A hospital-based retrospective study on frequency and distribution of viral hepatitis. J Global Infect Dis 2014;6(3):99-104. DOI: 10.4103/0974-777X.138499.

19. Manmohan G, Patil R, Khan Ml, et al. Retrospective hospital based study of infective causes of jaundice in Tamil Nadu, India. Calicut Med J 2011;9:1-4.

20. Mittal A, Bithu R, Vyas N, et al. Prevalence of hepatitis A virus and hepatitis $E$ virus in the patients presenting with acute viral hepatitis at a tertiary care hospital Jaipur, Rajasthan. N Niger J Clin Res 2016;5(8):47-50. DOI: 10.4103/2250-9658.197436.

21. Chadha MS, Walimbe AM, Chobe LP, et al. Comparison of etiology of sporadic acute and fulminant viral hepatitis in hospitalized patients in Pune, India, during 1978-81 and 1994-97. Indian J Gastroenterol 2003;22:11-15.

22. Das K, Agarwal A, Andrew $R$, et al. Role of hepatitis $E$ and other hepatotropic virus in aetiology of sporadic acute viral hepatitis: a hospital based study from urban Delhi. Eur J Epidemiol 2000;16(10):937-940. DOI: 10.1023/A:1011072015127.

23. Tandon BN, Gandhi BM, Joshi YK. Etiological spectrum of viral hepatitis and prevalence of markers of hepatitis $A$ and $B$ virus infection in north India. Bull World Health Organ 1984;62(1):67-73.

24. Suri $P$, Chhina D, Gupta V, et al. Seroprevalence of parenterally and enterally transmitted hepatitis viruses in a tertiary care hospital of North India - a two-year study. J Gastro Infs 2012;2(1):46-51.

25. Mishra B, SrinivasaH, Muralidharan S, et al. A hospital based study of hepatitis E by serology. Indian J Med Microbiol 2003;21(2):115-117.

26. Al-Naaimi AS, Turky AM, Khaleel HA, et al. Predicting acute viral hepatitis serum markers ( $A$ and $E$ ) in patients with suspected acute viral hepatitis attending primary health care centers in Baghdad: a one year cross-sectional study. Glob J Health Sci 2012;4:172-183. 
27. Kamal SM, Mahmoud S, Hafez T, et al. Viral hepatitis A to E in south mediterranean countries. Mediterr J Hematol Infect Dis 2010;2(1):e2010001.

28. Barrientos-Gutiérrez T, Brizuela-Alcántara D, Chávez-Tapia NC. Hepatitis A virus infection in high-risk subjects. Ann Hepatol 2011;10:578-579.

29. Al Faleh F, Al Shehri S, Al Ansari S, et al. Changing patterns of hepatitis A prevalence within the Saudi population over the last 18 years. World J Gastroenterol 2008;14(48):7371-7375. DOI: 10.3748/wjg.14.7371.

30. Dhamdhere MR, Nadkarni MG. Infectious hepatitis at Aurangabad. report of an outbreak. Indian J Med Sci 1962;16:1006-1015.

31. Kaur R, Gur R, Berry N, et al. Etiology of endemic viral hepatitis in urban North India. Southeast Asian J Trop Med Public Health 2002;33(4):845-848.
32. Sebastian B, Mathai S, Mathew G, et al. An outbreak of hepatitis A in central India: changing patterns. Indian J Gastroenterol 2001;20: 132-135.

33. Begum N, Devi SG, Husain SA, et al. Seroprevalence of subclinical $\mathrm{HEV}$ infection in pregnant women from north India: a hospital-based study. Indian J Med Res 2009;130(6):709-713.

34. Chandra NS, Sharma A, Rai RR, et al. Contribution of hepatitis Evirus in acute sporadic hepatitis in North Western India. Indian J Med Res 2012;136(3):477-482.

35. Ippagunta SK, Naik S, Sharma B, et al. Presence of hepatitis E virus in sewage in northern India: frequency and seasonal pattern. J Med Virol 2007;79(12):1827-1831. DOI: 10.1002/jmv.21017. 